\title{
EFFECTS OF RESERPINE, $p$-CHLOROPHENYLALANINE, $\alpha$-METHYLTYROSINE, THYMOXAMINE OR METHALLIBURE ON PITUITARY FSH IN MALE RATS
}

\author{
P. S. BROWN AND LINDA FAWKE
}

Department of Pharmacology, University of Bristol, Medical School, Bristol BS8 1TD

(Received 30th December 1970, accepted 19th fuly 1971)

\begin{abstract}
Summary. Drugs were injected on experimental Days 2 to 5 into mature male rats that were (1) intact, (2) castrated on Day 1, or (3) castrated on Day 1 and treated with testosterone. The animals were killed on Day 7 and the pituitary FSH content compared with that of controls. Methallibure prevented the rise in FSH content caused by testosterone in the third group and reduced pituitary FSH in intact rats: this may have resulted from inhibition of FSH synthesis. Methallibure increased pituitary FSH in castrated rats, probably by inhibiting its secretion. Reserpine increased FSH content in each type of animal and $p$-chlorophenylalanine increased it in all but intact rats: these drugs probably inhibit FSH secretion. The FSH content was reduced by $\alpha$ methyltyrosine in testosterone-treated castrated rats while thymoxamine increased it in such animals and in intact rats. These findings do not clarify the rôle of catecholamines in FsH secretion. The similarity of the effects of reserpine and $p$-chlorophenylalanine supports the suggestion that 5-hydroxytryptamine plays an excitatory rôle in FsH secretion.
\end{abstract}

\section{INTRODUCTION}

The pituitary content of FSH is influenced both by the rate of synthesis and by the rate of secretion of the hormone. Consequently, measurement of the pituitary store of FSH cannot, alone, give conclusive evidence of changes in either process. In certain circumstances, however, such measurements may provide evidence which is at least suggestive. It has, for example, been shown that the rapid depletion of pituitary FSH in female rats shortly before they attain sexual maturity (Fawke \& Brown, 1970) can be inhibited by treatment with sodium barbitone or reserpine (Brown, 1971). It was thought that the most probable interpretation of this finding was that these drugs inhibit the secretion of FSH. Treatment with $p$-chlorophenylalanine (CPA) which inhibits the synthesis of 5-hydroxytryptamine (5-HT) (Koe \& Weissman, 1966), or with methysergide which antagonizes $5-\mathrm{HT}$, also prevented the rapid fall in FsH content, suggesting that 5-HT may play an excitatory rôle in FSH secretion 
(Brown, 1971). To investigate further the involvement of the biogenic monoamines in pituitary gonadotrophic function, the effect on pituitary FSH content of drugs which modify their actions has now been tested in mature male rats. For reasons explained below, the animals used were intact and castrated males, and castrated males treated with testosterone. The drugs tested were reserpine, which depletes tissues of both 5-HT and catecholamines; CPA for its effect on the synthesis of $5-\mathrm{HT} ; \alpha$-methyltyrosine which inhibits catecholamine synthesis (Spector, Sjoerdsma \& Udenfriend, 1965); thymoxamine-an $\alpha$-adrenergic blocker (Birmingham \& Szolcsanyi, 1965), and methallibure because this drug probably inhibits the synthesis of FSH (Brown, 1963; Walpole, 1968).

Castration in the rat causes, after 7 or 8 days, an increase in the plasma FSH level with little change or a fall in pituitary FSH content (Steinberger \& Duckett, 1968; Watanabe \& McCann, 1969). Thus, castration appears to increase the rate of secretion of FSH. Treatment of the castrated rat with testosterone for 7 days starting on the day of castration has been shown to reduce the plasma levels of FSH but increase the pituitary FSH content (Steinberger \& Duckett, 1968). Similar changes were produced when treatment with testosterone was started 35 days after castration (Kamberi \& McCann, 1969). This suggests that testosterone reduces FSH secretion but does not inhibit its synthesis. After preliminary experiments to confirm that testosterone treatment caused a significant rise in pituitary FSH content in castrated rats from our colony, the effect of drugs was tested on this accumulation of hormone, which must represent newly synthesized hormone. Any drug which inhibits the synthesis of FsH would be expected to reduce the rise in hormone content. The drugs have also been tested on castrated rats not treated with testosterone: as secretion is enhanced in this situation, it was thought likely that drugs which inhibit secretion would increase pituitary content compared with that in control rats. For completeness and comparison, the effect of the drugs has also been tested on intact rats.

\section{MATERIALS AND METHODS}

\section{Animals}

Adult, male, Porton rats were used intact or were castrated through a scrotal incision under ether anaesthesia. At the end of the experiment, they were killed with chloroform and their anterior pituitaries quickly removed, weighed and homogenized in $0.9 \% \mathrm{NaCl}$ solution (saline). The homogenates were frozen and kept at $-20^{\circ} \mathrm{C}$ until assayed for FsH by a modification of the method of Steelman \& Pohley (1953). Details of the methods of storage and assay have been described previously (Fawke \& Brown, 1970). Body weight was recorded at the end of the experiment and in three-quarters of the experiments the mean weight of control rats ranged from 226 to $276 \mathrm{~g}$. When intact rats were used, the right testis, the seminal vesicles (together with coagulating glands) and the ventral prostate were weighed after fixation in formol-saline.

\section{Drugs}

Testosterone was injected subcutaneously in arachis oil either as the propionate (TP) or as a mixture of the propionate, phenylpropionate, isocaproate 
and decanoate marketed as Sustanon '250' (Organon). In the experiments with drugs, Sustanon was given in a single dose at the time of operation.

Methallibure (ICI) and DL-p-chlorophenylalanine (GPA) (Sigma, London) were suspended in saline containing methylcellulose. Saline was used as the solvent for DL-p-chlorophenylalanine methyl ester hydrochloride (CPA.ME) (Kistner Laboratories, Göteborg), DL- $\alpha$-methyltyrosine methyl ester hydrochloride (MPT.ME) (Kistner Laboratories, or Sigma) and thymoxamine hydrochloride (Warner). Reserpine (BDH) was dissolved in the vehicle described by Burack, Weiner \& Hagen (1960) and diluted with saline. All drugs were injected subcutaneously in a volume of 0.2 to $0.5 \mathrm{ml}$, between 10.00 and 12.00 hours, at a site remote from that used for the injection of Sustanon.

The effects of the drugs were tested in three situations: (1) rats were castrated and injected with $10 \mathrm{mg}$ Sustanon while still anaesthetized; drugs were injected daily for 5 days starting on the day after operation, (2) rats were castrated but not treated with testosterone; drugs were injected as in the previous group, (3) intact rats were injected with drugs daily for 5 days. In all groups, the rats were killed $24 \mathrm{hr}$ after the final injection of the drug: in castrated animals, this was 6 days after operation. The pituitary FSH content and concentration in drug-treated rats was compared by direct assay with that in rats treated with the vehicle alone.

\section{RESULTS}

In preliminary experiments, rats were injected with TP starting on the day of castration. They were given either $0.5 \mathrm{mg}$ TP daily or $1.5 \mathrm{mg}$ on alternate days. The pituitary FSH content 7 days after castration was significantly raised in rats treated with TP (Table 1). The pituitary content (and 95\% fiducial limits) in

TABLE 1

EFFECT OF TESTOSTERONE ON PITUITARY FSH CONTENT IN CASTRATED RATS

\begin{tabular}{c|c|c|c|c|c|c}
\hline $\begin{array}{c}\text { Exp. } \\
n o .\end{array}$ & $\begin{array}{c}\text { Testosterone } \\
\text { preparation }\end{array}$ & $\begin{array}{c}\text { Dose } \\
(\mathrm{mg})\end{array}$ & $\begin{array}{c}\text { No. of } \\
\text { doses }\end{array}$ & $\begin{array}{c}\text { Frequency } \\
\text { of } \\
\text { doses }\end{array}$ & $\begin{array}{c}\text { No. of rats } \\
\text { (treated/control) }\end{array}$ & $\begin{array}{c}\text { Pituitary FSH content of testosterone- } \\
\text { treated rats as \% of content of controls } \\
\text { (95\% fiducial limits) }\end{array}$ \\
\hline $1^{*}$ & $\begin{array}{c}\text { Testosterone } \\
\text { propionate }\end{array}$ & 0.5 & 6 & Daily & $6 / 7$ & 200 (144 to 277) \\
\hline 2 & 1.5 & 4 & $\begin{array}{c}\text { Alternate } \\
\text { days }\end{array}$ & $6 / 6$ & $276(185$ to 417) \\
\hline $\begin{array}{c}\text { Sustanon } \\
\text { '250' }\end{array}$ & 5 & 1 & - & $6 / 5$ & 235 (142 to 383) \\
& 10 & 1 & - & $6 / 5$ & $238(145$ to 383$)$ \\
20 & 1 & - & $6 / 5$ & $250(154$ to 405) \\
\hline
\end{tabular}

* Values of pituitary FSH content in terms of NIH.FSH in this experiment are quoted in the text.

castrated rats treated with the vehicle daily was equivalent to 171 (115 to 257) $\mu \mathrm{g}$ FSH.S6, and that of castrated rats injected with the vehicle on alternate days to 156 (104 to 231) $\mu \mathrm{g}$. The hormone content in the corresponding groups 
TABLE 2

EFFECT OF DRUGS ON PITUITARY FSH LEVELS IN CASTRATED RATS TREATED WITH TESTOSTERONE

\begin{tabular}{|c|c|c|c|c|}
\hline \multirow[t]{2}{*}{ Drug } & \multirow{2}{*}{$\begin{array}{l}\text { Daily } \\
\text { dose } \\
(m g)\end{array}$} & \multirow{2}{*}{$\begin{array}{c}\text { No. of rats } \\
\text { (drug-treated) } \\
\text { vehicle-treated })\end{array}$} & \multicolumn{2}{|c|}{$\begin{array}{c}\text { Pituitary FSH of drug-treated rats as } \\
\% \text { of that of rats treated with vehicle } \\
(95 \% \text { fiducial limits })\end{array}$} \\
\hline & & & Pituitary content & Pituitary concentration \\
\hline Methallibure & $\begin{array}{l}1 \\
2 \\
4 \\
6\end{array}$ & $\begin{array}{l}6 / 6 \\
6 / 6 \\
6 / 6 \\
6 / 6\end{array}$ & $\begin{array}{l}86(62 \text { to } 120) \\
81(62 \text { to } 105) \\
79(57 \text { to } 110) \\
69(52 \text { to } 90)\end{array}$ & $\begin{array}{l}96(69 \text { to } 133) \\
84(64 \text { to } 109) \\
77(56 \text { to } 107) \\
70(52 \text { to } 91)\end{array}$ \\
\hline Reserpine & $\begin{array}{l}0.015 \\
0.02 \\
0.03 \\
0.05 * *\end{array}$ & $\begin{array}{l}6 / 6 \\
5 / 5 \\
6 / 6 \\
5 / 5\end{array}$ & $\begin{array}{l}138(94 \text { to } 182) \\
134(98 \text { to } 186) \\
110(78 \text { to } 156) \\
108(78 \text { to } 150)\end{array}$ & $\begin{array}{l}154(105 \text { to } 204) \\
130(95 \text { to } 181) \\
118(83 \text { to } 167) \\
119(86 \text { to } 166)\end{array}$ \\
\hline CPA & $\begin{array}{l}10 \\
20 \\
20^{* *}\end{array}$ & $\begin{array}{l}6 / 6 \\
6 / 6 \\
8 / 9\end{array}$ & $\begin{array}{l}122(82 \text { to } 178) \\
130(87 \text { to } 206) \\
163(99 \text { to } 280)\end{array}$ & $\begin{array}{l}121(81 \text { to } 176) \\
133(89 \text { to } 211) \\
201(122 \text { to } 346)\end{array}$ \\
\hline MPT.ME & $\begin{array}{l}18 \\
36\end{array}$ & $\begin{array}{l}7 / 8 \\
5 / 8\end{array}$ & $\begin{array}{c}112(85 \text { to } 151) \\
58(41 \text { to } 84)\end{array}$ & $\begin{array}{c}114(86 \text { to } 153) \\
66(47 \text { to } 96)\end{array}$ \\
\hline Thymoxamine & $\begin{array}{l}0.6 \\
0 \cdot 8 \\
0 \cdot 8\end{array}$ & $\begin{array}{l}7 / 7 \\
6 / 7 \\
7 / 7\end{array}$ & $\begin{array}{l}94(64 \text { to } 152) \\
181(110 \text { to } 265) \\
152(100 \text { to } 231)\end{array}$ & $\begin{array}{l}99(68 \text { to } 161) \\
174(106 \text { to } 255) \\
149(98 \text { to } 226)\end{array}$ \\
\hline
\end{tabular}

$\mathrm{CPA}=p$-chlorophenylalanine $; \mathrm{MPT} . \mathrm{ME}=\mathrm{DL}-\alpha$-methyltyrosine methyl ester hydrochloride.

** These doses caused a significant reduction of body weight $(P<0.01)$ to $85 \%$ (GPA) or $86 \%$ (reserpine) of body weight in rats treated with vehicle.

TABLE 3

EFFEGT OF DRUGS ON PITUITARY FSH LEVELS IN CASTRATED RATS NOT TREATED WITH TESTOSTERONE

\begin{tabular}{|c|c|c|c|c|}
\hline \multirow[t]{2}{*}{ Drug } & \multirow{2}{*}{$\begin{array}{l}\text { Daily } \\
\text { dose } \\
(m g)\end{array}$} & \multirow{2}{*}{$\begin{array}{c}\text { No. of rats } \\
\text { (drug-treated) } \\
\text { vehicle-treated })\end{array}$} & \multicolumn{2}{|c|}{$\begin{array}{c}\text { Pituitary FSH of drug-treated rats as } \\
\% \text { of that of vehicle-treated rats } \\
(95 \% \text { fiducial limits })\end{array}$} \\
\hline & & & Pituitary content & Pituitary concentration \\
\hline Methallibure & $\begin{array}{l}6 \\
6\end{array}$ & $\begin{array}{l}7 / 7 \\
5 / 6\end{array}$ & $\begin{array}{l}173(95 \text { to } 300) \\
203(138 \text { to } 304)\end{array}$ & $\begin{array}{l}172(95 \text { to } 299) \\
226(153 \text { to } 338)\end{array}$ \\
\hline Reserpine & $\begin{array}{l}0.02 \\
0.04\end{array}$ & $\begin{array}{l}6 / 7 \\
7 / 7\end{array}$ & $\begin{array}{l}107(73 \text { to } 158) \\
145(98 \text { to } 215)\end{array}$ & $\begin{array}{l}106(72 \text { to } 157) \\
155(105 \text { to } 230)\end{array}$ \\
\hline CPA* & $\begin{array}{l}20 \\
20 \\
20\end{array}$ & $\begin{array}{l}6 / 7 \\
6 / 6 \\
5 / 6\end{array}$ & $\begin{array}{l}254(148 \text { to } 340) \\
105(78 \text { to } 143) \\
167(105 \text { to } 264)\end{array}$ & $\begin{array}{l}250(145 \text { to } 334) \\
109(81 \text { to } 149) \\
156(98 \text { to } 247)\end{array}$ \\
\hline MPT.ME* & $\begin{array}{l}18 \\
36\end{array}$ & $\begin{array}{l}6 / 7 \\
6 / 7\end{array}$ & $\begin{array}{l}78(52 \text { to } 117) \\
76(51 \text { to } 115)\end{array}$ & $\begin{array}{l}80(53 \text { to } 120) \\
76(51 \text { to } 115)\end{array}$ \\
\hline Thymoxamine & $\begin{array}{l}0.4 \\
0.8 \\
0.8\end{array}$ & $\begin{array}{l}6 / 7 \\
6 / 7 \\
6 / 6\end{array}$ & $\begin{array}{l}82(61 \text { to } 109) \\
83(62 \text { to } 110) \\
74(44 \text { to } 125)\end{array}$ & $\begin{array}{l}72(54 \text { to } 96) \\
79(59 \text { to } 104) \\
77(46 \text { to } 130)\end{array}$ \\
\hline
\end{tabular}

None of these drugs caused a significant reduction in body weight. The maximum reduction, to $89 \%$ of control weight, was caused by methallibure.

* Abbreviations as for Table 2. 
treated with TP was equivalent to 340 (250 to 472 ) and 430 (285 to 640 ) $\mu \mathrm{g}$ FSH.S6, respectively. In a second experiment, a single injection of Sustanon was given at the time of castration and the rats were killed 7 days later. The results show (Table 1) that the lowest dose used $(5 \mathrm{mg} / \mathrm{animal}$ ) was probably as effective in increasing FSH content as the higher doses but, to be sure that maximal doses were used, an injection of $10 \mathrm{mg}$ Sustanon was used in all the experiments described below.

The effects of drug treatment on pituitary FSH content and concentration are shown by the results summarized in Tables 2 to 4 .

TABLE 4

EFFECT OF DRUGS ON PITUITARY FSH LEVELS IN INTACT RATS

\begin{tabular}{|c|c|c|c|c|}
\hline \multirow[t]{2}{*}{ Drug } & \multirow{2}{*}{$\begin{array}{l}\text { Daily } \\
\text { dose } \\
(m g)\end{array}$} & \multirow{2}{*}{$\begin{array}{c}\text { No. of rats } \\
\text { (drug-treated) } \\
\text { vehicle-treated) }\end{array}$} & \multicolumn{2}{|c|}{$\begin{array}{c}\text { Pituitary FSH of drug-treated rats as } \\
\% \text { of that of rats treated with vehicle } \\
(95 \% \text { fiducial limits })\end{array}$} \\
\hline & & & Pituitary content & Pituitary concentration \\
\hline Methallibure & 6 & $7 / 7$ & $46(26$ to 81$)$ & $47(27$ to 83$)$ \\
\hline Reserpine & $\begin{array}{l}0.01 \\
0.02\end{array}$ & $\begin{array}{l}6 / 7 \\
6 / 7\end{array}$ & $\begin{array}{l}119(79 \text { to } 178) \\
154(101 \text { to } 233)\end{array}$ & - \\
\hline CPA.ME $\dagger$ & 20 & $4 / 7$ & 142 (88 to 226 ) & $130(81$ to 207$)$ \\
\hline CPAt & $20^{*}$ & $8 / 7$ & $100(62$ to 163$)$ & 118 (73 to 192$)$ \\
\hline MPT.ME $\ddagger$ & 36 & $6 / 8$ & $94(61$ to 147$)$ & 95 (62 to 148$)$ \\
\hline Thymoxamine & $\begin{array}{l}0.8 \\
0.8\end{array}$ & $\begin{array}{l}7 / 7 \\
6 / 8\end{array}$ & $\begin{array}{l}173(108 \text { to } 276) \\
125(75 \text { to } 207)\end{array}$ & $\begin{array}{l}171(107 \text { to } 273) \\
126(75 \text { to } 208)\end{array}$ \\
\hline
\end{tabular}

The organ weights of these rats are described in the text.

* This dose caused significant $(P<0.05)$ reduction to $91 \%$ of control body weight.

$\dagger$ CPA.ME = DL-p-chlorophenylalanine methyl ester hydrochloride.

$¥$ Abbreviations as for Table 2 .

\section{Methallibure}

Methallibure treatment of the castrated testosterone-treated rat reduced the pituitary content of FSH (Table 2). The effect increased with increasing dose and became statistically significant at a dose of $6 \mathrm{mg} /$ day, a level which did not alter body weight (the weight of drug-treated rats was $98 \%$ of that of vehicle-treated animals). The same dose of methallibure also caused a significant reduction (to $46 \%$ ) in pituitary FSH content in intact rats (Table 4 ).

In the castrated rat without steroid treatment, methallibure produced the opposite effect (Table 3): a dose of $6 \mathrm{mg} /$ day in one experiment caused a statistically significant doubling of hormonal content and concentration.

\section{Reserpine}

Treatment with reserpine caused a moderate increase in pituitary FSH content in each type of rat (Tables 2 to 4 ). The effect was consistent but in individual experiments was barely significant statistically: pituitary FSH concentration was increased in parallel and just reached significance. 


\section{p-Chlorophenylalanine}

In the castrated testosterone-treated rat, CPA caused a consistent increase in pituitary FSH content (Table 2). The effect on hormone content was almost statistically significant at the dose of $20 \mathrm{mg} /$ day, and the rise in pituitary FSH concentration was significant $(P<0 \cdot 05)$. In two experiments in the castrated rat without testosterone treatment, the same dose produced significant increases in pituitary content to 254 and $167 \%$ of that in vehicle-treated rats, but a third experiment did not show a significant increase (Table 3 ). The drug produced no significant changes in the FsH levels in the intact rat (Table 4).

\section{$\alpha$-Methyltyrosine methyl ester hydrochloride}

In doses up to $36 \mathrm{mg} / \mathrm{day}$, MPT.ME produced no significant changes in pituitary FSH content or concentration except in the castrated testosteronetreated rat when both were significantly reduced by the higher dose (Table 2).

\section{Thymoxamine}

Thymoxamine, $800 \mu \mathrm{g} /$ day, produced significant increases in pituitary FSH, both in castrated, testosterone-treated rats (Table 2) and in intact rats (Table 4). In castrated rats without steroid treatment, however, this drug produced no significant change in FSH levels and, if anything, depressed them.

\section{Organ weights in intact rats}

Methallibure (6 mg/day) did not cause a significant fall in body weight (which was $94 \%$ of that of the controls), but seminal vesicle weight was reduced to $61 \%(P<0.001)$ and ventral prostate weight to $80 \%(P<0.1)$ of that of the controls. Reserpine, 10 and $20 \mu \mathrm{g} / \mathrm{day}$, did not alter body weight but increased seminal vesicle weight to $124 \%(P<0.05)$ and $151 \%(P<0.01)$, respectively, of the control values: ventral prostate weight was raised to 113 and $127 \%$ but the increase was not statistically significant. In doses of $20 \mathrm{mg} / \mathrm{day}$, CPA.ME caused a significant $(P<0.05)$ reduction in ventral prostate weight to $85 \%$ of that of the control. Similar doses of CPA caused a significant fall in body weight (to $91 \%$; $P<0.05)$ but no significant change in organ weights. The compound MPT.ME was tested at a dose of $36 \mathrm{mg} /$ day and thymoxamine at $800 \mu \mathrm{g} /$ day but neither altered body, seminal vesicle or ventral prostate weights. None of the drugs in the doses used caused significant alteration of testis weight.

\section{DISGUSSION}

The reduction in pituitary FSH content caused by methallibure in castrated, testosterone-treated rats is compatible with the hypothesis that this drug reduces the synthesis of FSH (Brown, 1963; Walpole, 1968). A similar effect in intact rats confirms previous observations (Brown, 1963) and supports the same hypothesis. The increase in pituitary FsH content (as compared with vehicletreated controls) in the castrated rats not treated with testosterone suggests that methallibure also prevents the secretion of FSH, and that the increased secretion in this situation may be more sensitive to inhibition by the drug than the 
synthetic process. Methallibure prevents the fall in pituitary FSH in maturing female rats (Brown, 1971) and during the oestrous cycle in the pig (Garbers \& First, 1969). Inhibition of FSH secretion would explain these findings as well as the inhibition of testicular growth in rats and mice treated with methallibure (Brown, 1963; Fawke, Morris \& Brown, 1972).

The increase in pituitary FSH caused by reserpine in all three situations is probably best explained by inhibition of FSH secretion, stimulation of synthesis being less likely. Increases over control levels in pituitary FSH caused by reserpine in female rats have been reported by Labhsetwar (1967), and reserpine has been shown to prevent the fall in FSH in 35-day-old female rats (Brown, 1971). Reserpine has also been reported to reduce the FsH-releasing activity in the blood of hypophysectomized rats (Negro-Vilar, Dickerman \& Meites, 1968). If it is accepted that the effects of the drug are due to inhibition of Fsh secretion, it seems that some degree of secretory activity is continuing in the castrated rats treated with testosterone.

The effects of CPA can also be explained on the assumption that it inhibits FSH secretion. This is supported by the fact that the effect was greatest, though not consistent, in castrated rats in which secretion is thought to be increased. This interpretation would agree with the findings in maturing female rats in which CPA prevented the rapid fall in pituitary FSH (Brown, 1971). In the same series of experiments, it was shown that treatment with GPA decreased the ovarian enlargement caused by injection of HGG into immature rats, a response which is thought to be largely dependent on endogenous FSH release. All these observations are compatible with the hypothesis that CPA inhibits FSH secretion. If it does, it presumably acts by preventing the synthesis of 5-HT and this suggests that 5-HT may play an excitatory rôle in FsH secretion in the rat. Such a mechanism would contrast sharply with that controlling the ovulatory surge of LH which seems to be inhibited by 5-HT (Kordon, Javoy, Vassent \& Glowinski, 1968). This possible involvement of 5-HT in the secretion of FSH is discussed more fully elsewhere (Brown, 1971).

The results of treatment with MPT.ME are not very striking except for the significant fall in pituitary FSH content which occurred with the higher dose in the castrated, testosterone-treated animals. This dose did not cause any obvious toxic effects and only reduced the body weight of treated rats to $95 \%$ of that of the controls: the effect may therefore be a specific result of the blockade of catecholamine synthesis. There was, however, no similarity between the effects of MPT.ME and those of the $\alpha$-adrenergic-blocking drug, thymoxamine. This substance produced changes in FSH content which are difficult to interpret. It seems unlikely that, in this instance, the increase in pituitary content found in the castrated, testosterone-treated rat was due to inhibition of FSH secretion, considering that a similar effect was not found in the castrated rat in the absence of treatment with TP. The rise in the former animals and that found in intact rats may, therefore, have been due to stimulation of the synthesis of FSH by thymoxamine. This possibility was suggested when interpreting the effect of the same drug on pituitary FSH in immature female rats (Brown, 1971) and in this context it was suggested that thymoxamine might also increase FsH secretion. However, before ascribing these actions to adrenergic blockade, it must be 
noted that thymoxamine has other activities: it is, for example, antihistaminic (Birmingham \& Szolcsanyi, 1965).

There were no significant changes in testicular weight in the intact rats treated with drugs, so that these results do not help in the interpretation of changes in pituitary FSH levels. The reduction in seminal vesicle weight by methallibure was expected, but the increase in seminal vesicle weight in rats treated with reserpine was not foreseen as it had been expected to fall because of an inhibition of secretion of LH. A similar effect was found in mice (Fawke et al., 1972) but no indication was obtained as to the site of action of reserpine: this could be anywhere from the central nervous system to the seminal vesicle itself. The significant reduction in ventral prostate weight produced by CPA.ME is also paralleled by the reduction in seminal vesicle weight in hemicastrated mice (Fawke et al., 1972). These findings suggest that depletion of tissue 5-HT may inhibit the secretion of LH under some circumstances, a suggestion which would explain the reported blockade of induced ovulation in immature mice by CPA (Brown, 1968).

\section{ACKNOWLEDGMENTS}

This work was supported in part by grants from the Population Council and the Smith Kline and French Foundation. We are also grateful to Dr A. L. Walpole and ICI Ltd for supplies of methallibure and to Dr M. R. Yapp and William R. Warner \& Co. for thymoxamine. Ovine FsH was kindly supplied by the National Institutes of Health, U.S.A.

\section{REFERENCES}

Birmingham, A. T. \& Szolcsanyi, J. (1965) Competitive blockade of adrenergic $\alpha$-receptors and histamine receptors by thymoxamine. 7 . Pharm. Pharmac. 17, 449.

BRown, P. S. (1963) Observations on a dithiocarbamoylhydrazine as an inhibitor of pituitary gonadotrophic activity. 7. Endocr. 26, 425.

Brown, P. S. (1968) The effect of drugs on induced ovulation. F. Reprod. Fert. Suppl. 4, 61.

BRown, P. S. (1971) Pituitary follicle stimulating hormone in immature female rats treated with drugs that inhibit the synthesis or antagonise the actions of catecholamines and 5-hydroxytryptamine. Neuroendocrinology, 7, 183.

Burack, W. R., Weiner, N. \& Hagen, P. B. (1960) The effect of reserpine on the catecholamine and adenine nucleotide content of adrenal glands. F. Pharmac. exp. Ther. 130, 245.

FAWKe, L. \& BROWN, P. S. (1970) Pituitary content of follicle-stimulating hormone in the female rat. 7. Reprod. Fert. 21, 303.

Fawke, L., Morris, A. \& Brown, P. S. (1972) Effects of hemicastration and the subsequent administration of drugs in the mouse. F. Reprod. Fert. 28, 177.

Garbers, D. L. \& First, N. L. (1969) The effects of injected oestradiol-17 $\beta$, progesterone and dietary ICI 33828 on ovarian and pituitary functions in the sow and gilt. $\mathcal{F}$. Reprod. Fert. 20, 451.

Kamberi, I. A. \& MaCanN, S. M. (1969) Effect of testosterone implants in the anterior pituitary on Fsh secretion. Fedn Proc. Fedn Am. Socs exp. Biol. 28, 382.

Koe, B. K. \& Weissman, A. (1966) p-Chlorophenylalanine: a depletor of brain serotonin. F. Pharmac. exp. Ther. 154, 499.

Kordon, G., Javoy, F., Vassent, G. \& Glowinski, J. (1968) Blockade of superovulation in the immature rat by increased brain serotonin. Europ. F. Pharmac. 4, 169.

LABHSETWAR, A. P. (1967) Differential effects of reserpine on pituitary luteinizing hormone and follicle-stimulating hormone levels in the female rat. Endocrinology, 81, 357.

Negro-Vilar, A., Digkerman, E. \& Meites, J. (1968) Removal of plasma Fsh-RF activity in hypophysectomized rats by testosterone propionate or reserpine. Endocrinology, 83, 1349.

SPECTOR, S., SJOERDsma, A. \& Udenfriend, S. (1965) Blockade of endogenous norepinephrine synthesis by $\alpha$-methyl-tyrosine, an inhibitor of tyrosine hydoxylase. 7 . Pharmac. exp. Ther. 147, 86 . 
Steelman, S. L. \& Pohley, F. S. (1953) Assay of follicle stimulating hormone based on the augmentation with human chorionic gonadotropin. Endocrinology, 53, 604.

Strinberger, E. \& Ducketr, G. (1968) Effect of testosterone propionate on the release of FsH from the pituitary gland. Acta endocr., Copenh. 57, 289.

Walpole, A. L. (1968) Non-steroidal drugs in relation to ovulation and implantation. F. Reprod. Fert. Suppl. 4, 3.

Watanabe, S. \& MCGann, S. M. (1969) Effects of castration or testosterone treatment on hypothalamic FSH-RF and pituitary FSH of male rats. Proc. Soc. exp. Biol. Med. 130, 1075. 